\title{
Proteomic analysis of cold adaptation in a Siberian permafrost bacterium - Exiguobacterium sibiricum 255-15 by two-dimensional liquid separation coupled with mass spectrometry
}

\author{
Yinghua Qiu ${ }^{1}$, Sophia Kathariou ${ }^{2}$ and David M. Lubman, 3 \\ ${ }^{1}$ Department of Chemistry, University of Michigan, Ann Arbor, MI, USA \\ ${ }^{2}$ Department of the Food Science, North Carolina State University, Raleigh, NC, USA \\ ${ }^{3}$ Department of Surgery, University of Michigan Medical Center, Ann Arbor, MI, USA
}

Bacterial cold adaptation in Exiguobacterium sibiricum 255-15 was studied on a proteomic scale using a 2-D liquid phase separation coupled with MS technology. Whole-cell lysates of E. sibiricum $255-15$ grown at $4^{\circ} \mathrm{C}$ and $25^{\circ} \mathrm{C}$ were first fractionated according to $\mathrm{p} I$ by chromatofocusing (CF), and further separated based on hydrophobicity by nonporous silica RP HPLC (NPS-RPHPLC) which was on-line coupled with an ESI-TOF MS for intact protein $M_{\mathrm{r}}$ measurement and quantitative interlysate comparison. Mass maps were created to visualize the differences in protein expression between different growth temperatures. The differentially expressed proteins were then identified by PMF using a MALDI-TOF MS and peptide sequencing by MS/MS with a MALDI quadrupole IT TOF mass spectrometer (MALDI-QIT-TOF MS). A total of over 500 proteins were detected in this study, of which 256 were identified. Among these proteins 39 were cold acclimation proteins (Caps) that were preferentially or uniquely expressed at $4^{\circ} \mathrm{C}$ and three were homologous cold shock proteins (Csps). The homologous Csps were found to be similarly expressed at $4^{\circ} \mathrm{C}$ and $25^{\circ} \mathrm{C}$, where these three homologous Csps represent about $10 \%$ of the total soluble proteins at both $4^{\circ} \mathrm{C}$ and $25^{\circ} \mathrm{C}$.

\section{Keywords:}

2-D liquid phase separation / Bacterial cold adaptation / ESI-TOF MS / MALDI-TOF MS / MALDI-OIT-TOF MS
Received: January 27, 2006

Revised: June 9, 2006

Accepted: June 14, 2006

\section{Introduction}

Low temperature is a predominant environmental characteristic of most parts of the earth's surface. Approximately $70 \%$ of the earth's surface is covered by oceans with an aver-

Correspondence: Professor David M. Lubman, University of Michigan, Department of Surgery, MSRB1 RmA510B, 1150 West Medical Center Drive, Ann Arbor, MI 48109, USA

E-mail: dmlubman@umich.edu

Fax: +1-734-760-6199

Abbreviations: ACTH, adrenocorticotropic hormone; Caps, cold acclimation proteins; CF, chromatofocusing; Csps, cold shock proteins; EB, elute buffer; Hsp70, heat shock protein 70; OG, $n$-octyl- $\beta$-D-glucopyranoside; PspA, phage shock protein A; $\mathbf{S B}$, start buffer; TF, trigger factor age temperature of $4^{\circ} \mathrm{C}$ while over $20 \%$ is occupied by permafrost. Often, in these harsh environments, the only form of life is bacteria [1-5]. These bacteria have apparently developed various adaptive mechanisms that allow them to survive in such hostile environmental conditions through longterm evolutionary processes. Among such adaptive processes, not only the bacteria themselves might be affected by environmental low temperature and induced cold adapted features, but also the production of organic molecules within them, such as enzymes and proteins that sustain their metabolism. In the discussion of bacterial low temperature adaptation, specific sets of cold shock proteins (Csps) and cold acclimation proteins (Caps) have been considered to facilitate and allow cell growth at low temperature. The term "Csps" is used here for proteins that are transiently overexpressed after an abrupt shift to a low temperature, and the 
term "Caps" is used for proteins synthesized at a greater level during continuous growth at low temperature as compared with high temperature. The response to cold temperature has been extensively studied in mesophilic, psychrotrophic, and psychrophilic bacteria such as Escherichia coli [6-18], Bacillus subtilis [19-30], Bacillus cereus [31], Bacillus psychrophilus [32], Arthrobacter globiformis SI55 [33, 34], Enterococcus faecalis [35], Listeria monocytogenes [36-38], Mycobacterium tuberculosis [39], Pseudomonas fragi [40-42], Salmonella typhimurium [43-45], Streptomyces clavuligerus [46], and Trichosporon pullulans [47]. The mechanism of bacterial response to cold temperature is still poorly understood, while this problem is of great importance with regard to ecological safety and the development of ecological biotechnologies in the temperate and subpolar climatic regions.

Exiguobacterium sibiricum 255-15 is a nonspore forming Gram-positive bacterium of the family Bacillaceae and was first isolated from a 2 to 3 million-year-old Siberian permafrost sediment [48]. This bacterium strain was found to grow well at $-2.5^{\circ} \mathrm{C}$ and remain physiologically active down to at least $-12^{\circ} \mathrm{C}[49,50]$. This strain was chosen for sequencing based on its excellent survival after a long-term freeze, rapid growth at low temperature and the age of the permafrost sediment from which it was originally isolated. E. sibiricum 255-15, together with other permafrost inhabiting bacteria, may serve as a model for low temperature exobiological niches on Mars and other planets and satellites in our solar system.

Bacterial cold adaptation at the protein level has been most successful when applied to small sets of proteins isolated in specific functional contexts. However, to be biologically useful, as opposed to simply highlighting analytical methods, large-scale proteomic studies are needed to underlie all cellular processes. No method or instrument exists that is able to identify and quantify the components of complex protein samples in a simple, single-step operation. Rather, different components for separation, identification, and quantification as well as tools for data analysis must be combined together [51]. We have developed a 2-D liquid separation-based proteomic technology to compare protein profiling in human cells [52-58] as well as bacterial samples [59]. The entire method is performed in the liquid phase and, consequently, could be directly coupled with ESI-TOF MS for accurate intact protein $M_{\mathrm{r}}$ measurement and interlysate quantification. MS-based interlysate quantification provides high reproducibility compared with 2-DE in which poor reproducibility is always an issue for comparing sample-tosample protein expression.

In the present work, the 2-D liquid phase separation coupled with ESI-TOF MS, MALDI-TOF MS, and MALDIQIT-TOF MS has been demonstrated to be a rapid and effective means to study cold adaptation in E. sibiricum 25515 at the proteome-wide scale. The accurate $M_{\mathrm{r}}$ from ESITOF MS that is not available in 2-DE separation, together with $\mathrm{p} I$, provides an essential factor for protein identification in complex protein samples. As a result, over 500 proteins were resolved in the 2-D liquid separation and 256 of which were positively identified by PMF with MALDI-TOF MS and peptide sequencing by MS/MS using MALDI-QIT-TOF MS. Among these proteins 39 Caps were preferentially or uniquely expressed at low temperatures, which are probably one of the key determinants that allow life at low temperatures.

\section{Materials and methods}

\subsection{Chemicals}

BSA, DTT, $n$-octyl- $\beta$-D-glucopyranoside (OG), glycerol, phenylmethanesulfonyl fluoride (PMSF), iminodiacetic acid, TFA, ammonium bicarbonate $\left(\mathrm{NH}_{4} \mathrm{HCO}_{3}\right)$, urea, thiourea, Tris-base, 1,3-bis[tris(hydroxymethyl methylamino] propane (Bis-tris propane), $\alpha$-cyanohydroxycinnamic acid (CHCA), angiotensin I, angiotensin II, human adrenocorticotropic hormone (ACTH) fragment 1-17, ACTH fragment 18-39, bradykinin fragment $1-7, \mathrm{P} 14 \mathrm{R}$, sodium chloride $(\mathrm{NaCl})$, hydrochloric acid (37\%), HPLC-grade ACN, and 2-isopropanol were purchased from Sigma-Aldrich (St. Louis, MO, USA). N-tosyl-l-phenylalanine chloromethyl ketone (TPCK)-treated trypsin was supplied from Promega (Madison, WI, USA). Formic acid (98-100\%) was purchased from Riedel de Haen (Seelze, Germany). Tryptic soy broth (Difco) and yeast extract (Difco) were obtained from Fisher Scientific. Polybuffer 74 and 96 were purchased from Amersham Pharmacia Biotech (Piscataway, NJ). 2,5-Dihydroxy benzoic acid (DHB) was purchased from LaserBio Labs (SophiaAntipolis, Cedex, France). Deionized water was obtained using a Milli-Q water filtration system (Millipore, Bedford, MA).

\subsection{Cell culture and sample preparation}

The E. sibiricum 255-15 cell pellets used in this study were obtained from the Department of the Food Science at North Carolina State University. All cells were cultured in tryptic soy broth with $7 \%$ yeast extract to mid-log phase (OD $=0.7$ ). The cells were washed with $50 \mathrm{mM}$ Tris- $\mathrm{HCl}(\mathrm{pH} 7.5)$ for three times before they were frozen at $-80^{\circ} \mathrm{C}$. The cell pellets were shipped on dry ice.

Cell pellets $0.2-0.5 \mathrm{~g}$ were resuspended in $5 \mathrm{~mL}$ of lysis buffer ( $\mathrm{pH} 7.3$ ) containing $50 \mathrm{mM}$ Tris- $\mathrm{HCl}, 6 \mathrm{M}$ urea, $2 \mathrm{M}$ thiourea, 0.1 M DTT, 2\% OG, and $2 \mathrm{mM} \mathrm{PMSF}$ and then vortexed for $2 \mathrm{~min}$. After being sonicated for $10 \mathrm{~min}$, cell walls and other insoluble debris were removed by centrifugation at $40000 \mathrm{rpm}$ for $20 \mathrm{~min}$ at $4^{\circ} \mathrm{C}$ (Model L-70 Ultracentrifuge, $80 \mathrm{Ti}$ Rotor, Beckman-Coulter, Fullerton, CA, USA). The resulting whole-cell lysates were desalted using a PD-10 Sephadex G-25 gel filtration column (Amersham Biosciences, Piscataway, NJ, USA) and the protein concentration was determined using the Bradford-based protein assay (BioRad, Hercules, CA, USA) with BSA as a standard. 


\subsection{Chromatofocusing}

A Beckman Gold HPLC equipped with model 127S pump and model 166 detector (Beckman-Coulter) was used in the $\mathrm{CF}$ separation. The separation was performed on an HPCF1D column $(250 \mathrm{~mm} \times 2.1 \mathrm{~mm})$ (Eprogen, Darien, IL) on which a linear $\mathrm{pH}$ gradient was generated using a start buffer (SB) and elute buffer (EB). The upper limit of the $\mathrm{pH}$ gradient was determined by the SB $(25 \mathrm{mM}$ Bis-tris propane, $\mathrm{pH} 8.5)$ and the lower limit was determined by the EB (3\% v/ v polybuffer $74,7 \% \mathrm{v} / \mathrm{v}$ polybuffer $96, \mathrm{pH} 4.0)$. Both buffers were prepared in $6 \mathrm{M}$ urea and $0.1 \%$ OG with the $\mathrm{pH}$ adjusted using iminodiacetic acid. A total of $5 \mathrm{mg}$ extracted proteins were loaded on the CF column that was equilibrated at $0.2 \mathrm{~mL} / \mathrm{min}$ with the $\mathrm{SB}$ for $2 \mathrm{~h}$ followed by elution with the $\mathrm{EB}$ at the same flow rate. After the $\mathrm{pH}$ gradient was finished, the column was washed with $1 \mathrm{M} \mathrm{NaCl}$ solution to elute the proteins with the $\mathrm{p} I$ values lower than 4.0. The $\mathrm{pH}$ was detected online by an off-column $\mathrm{pH}$ electrode (Lazar Research Laboratories, Los Angeles, CA) and the separation was monitored at $280 \mathrm{~nm}$. Effluent from the CF separation was collected from pH 8.5 to 4.0 every $0.3 \mathrm{pH}$ unit intervals. All fractions were then stored at $-80^{\circ} \mathrm{C}$ for NPS-RP-HPLC separation.

\subsection{NPS-RP-HPLC online coupled with ESI-TOF MS}

Using the same HPLC system, the NPS-RP-HPLC separation was performed at a flow rate of $0.5 \mathrm{~mL} / \mathrm{min}$ on a $33 \mathrm{~mm} \times 4.6 \mathrm{~mm}$ ODS III column packed with $1.5 \mu \mathrm{m}$ nonporous silica beads (Eprogen). The column temperature was maintained at $60^{\circ} \mathrm{C}$ using a Model 7971 column heater (Jones Chromatography, Resolution Systems, Holland, MI, USA) to improve the resolution and speed of separation. The separation was performed using a water (solvent A) and ACN (solvent B) gradient; both of which contained $0.1 \% \mathrm{v} / \mathrm{v}$ TFA. The gradient profile used was as follows: (1) 5-26\% B in $1 \mathrm{~min}$; (2) 26-35\% B in $3.5 \mathrm{~min}$; (3) 35-40\% B in $9.5 \mathrm{~min}$; (4) 40-50\% B in $13 \mathrm{~min}$; (5) 50-58\% B in $4 \mathrm{~min}$; (6) 58-75\% B in $1 \mathrm{~min}$; (7) $75-100 \%$ B in $1 \mathrm{~min}$; (8) 100-5\% B in 1 min.

A postcolumn splitter was used after NPS-RP-HPLC so that half of the effluent was collected for further MS-based identification and the other half was directly online monitored by the ESI-TOF MS (LCT, Micromass, Manchester, UK). To improve the ionization efficiency, a $10 \%$ formic acid solution was continuously infused into the splitter at $5 \mu \mathrm{L} / \mathrm{min}$ by a syringe pump to be mixed with the effluent before being delivered into the ionization source. The LCT parameters were set as follows: capillary voltage at $3200 \mathrm{~V}$, sample cone at $45 \mathrm{~V}$, extraction cone at $3 \mathrm{~V}$, reflection lens voltage at $750 \mathrm{~V}$, desolvation temperature at $250^{\circ} \mathrm{C}$, source temperature at $120^{\circ} \mathrm{C}$, desolvation gas at $600 \mathrm{~L} / \mathrm{h}$, and nebulizer gas flow at the maximum. ESI-TOF MS was externally calibrated by directly infusing NaI-CsI standard solution and internally normalized by adding $1 \mu \mathrm{g}$ of insulin as a standard for the quantification of each protein based on its peak area. During the separation, one spectrum was acquired per second. The intact $M_{\mathrm{r}}$ was obtained by deconvoluting the multiplecharged-ion umbrella of the ESI-TOF MS spectra into a MaxEnt spectrum on a real-mass scale by MassLynx 4.0 software (Micromass). Deconvolution was performed using a target mass range of 4-95 kDa, 1 Da resolution, 0.75 Da peak width, and $65 \%$ peak height value.

\subsection{Tryptic digestion}

The collected NPS-RP-HPLC fractions were first concentrated to $80 \mu \mathrm{L}$ by a SpeedVac concentrator (Centrivap Concentrator, Labconco, Kansas City, Missouri, USA) to remove $\mathrm{ACN}$ and TFA followed by the addition of $10 \mu \mathrm{L}$ of $1 \mathrm{M} \mathrm{NH}_{4} \mathrm{HCO}_{3}$ and $10 \mu \mathrm{L}$ of $100 \mathrm{mM}$ DTT to neutralize the remaining TFA and to denature the protein. The mixtures were incubated at $37^{\circ} \mathrm{C}$ for $20 \mathrm{~min}$, and then $0.5 \mu \mathrm{g}$ TPCKtreated trypsin was added to start the digestion. The digestion was maintained at $37^{\circ} \mathrm{C}$ for $24 \mathrm{~h}$ and terminated by adding $2 \mu \mathrm{L}$ TFA. Before MS-based identification, tryptic digests were desalted and preconcentrated in $5 \mu \mathrm{L}$ of $60 \%$ ACN with 0.1\% TFA using $2 \mu \mathrm{m}$ C18 Zip-Tips (Millipore).

\subsection{MALDI-TOF MS}

In preparation for MALDI-TOF MS analysis, a saturated CHCA matrix solution in $60 \%$ ACN with $0.1 \%$ TFA was freshly prepared. Angiotensin I ([M + H $]^{+}$1296.69), ACTH 1-17 $\left([\mathrm{M}+\mathrm{H}]^{+}\right.$2093.09), and ACTH 18-39 $\left([\mathrm{M}+\mathrm{H}]^{+}\right.$ 2465.20) were added as internal standards into $1: 4$ diluted matrix solution and $0.5 \mu \mathrm{L}$ of the resulting solution was spotted on a 96-spot MALDI plate (Micromass) followed by layering $0.5 \mu \mathrm{L}$ peptide sample on top of the spot.

Peptide mass was measured on a Micromass TofSpec2E system (Micromass/Waters, Milford, MA, USA) equipped with a $337 \mathrm{~nm}$ nitrogen laser source and delayed extraction. The MALDI-TOF MS was operated in positive ion reflector mode and the parameters were set as follows: reflectron voltage at $25 \mathrm{kV}$, operating voltage at $20 \mathrm{kV}$, pulse voltage at $2 \mathrm{kV}$, delay time at $520 \mathrm{~ns}$, reflectron ratio at $1: 3$, suppression setting at $500 \mathrm{~V}$, and sampling rate at $2 \mathrm{GHz}$. The final MALDI spectrum was summed over the average of 100-150 spectra and calibrated with the three internal standards within $50 \mathrm{ppm}$. The peptide masses were obtained using MassLynx 4.0 over the range of 800-4000 Da and then submitted to MS-Fit (http://prospector.ucsf.edu/ucsfhtml4.0/ msfit.htm) for protein identification. The NCBInr database was searched with a mass tolerance of $50 \mathrm{ppm}$ and one missed cleavage set as fixed parameters.

\subsection{MALDI-OIT-TOF MS/MS peptide fragmentation and sequencing}

Mass spectrometric peptide fragmentation and sequencing were performed on an Axima MALDI-QIT-TOF mass spectrometer (Shimadzu Corporation, Kyoto, Japan and Kratos 
Analytical, Manchester, UK) equipped with a $337 \mathrm{~nm}$ nitrogen laser source. MALDI-TOF MS/MS analysis was performed in the positive ion mode using an external calibration with a mixture of bradykinin fragment $1-7\left([\mathrm{M}+\mathrm{H}]^{+}\right.$ 757.40), angiotensin II $\left([\mathrm{M}+\mathrm{H}]^{+} 1046.54\right), \mathrm{P} 14 \mathrm{R}\left([\mathrm{M}+\mathrm{H}]^{+}\right.$ 1533.86), and ACTH fragment 18-39 $\left([\mathrm{M}+\mathrm{H}]^{+} 2465.20\right)$. The matrix used in this case was a DHB solution with a concentration of $10 \mathrm{mg} / \mathrm{mL}$. Each MALDI-QIT-TOF profile resulted from the accumulation of five laser shots. The signal was further processed and analyzed by Lanchpad software (Kratos Analytical). The parent ion mass and the resulting fragment ion masses were searched against the NCBInr database using MASCOT 1.8 (Matrix Science, London, UK) setting a peptide tolerance of $1.2 \mathrm{Da}$, a MS/MS tolerance of 0.6 Da, and one missed cleavage site as fixed parameters.

\section{Results and discussion}

\subsection{Protein purification using 2-D liquid phase separation}

Using the 2-D liquid phase separation method followed by ESI-TOF MS intact protein molecular mass measurement, 2-D mass maps as shown in Fig. 1 were generated to visualize the protein profiling of E. sibiricum 255-15 at different growth temperatures. 2-D mass maps are analogous to 2-DE images but in a more advanced digitized format. The 18 lanes in the mass map represented $18 \mathrm{pI}$ fractions from the 1-D CF separation. The first three lanes were the $\mathrm{NaCl}$ wash fractions and the other lanes were the $\mathrm{pH}$ gradient fractions starting with $\mathrm{pH} 4.0-4.3$ at lane 4 and ending up with pH 8.2-8.5 at lane 18. Approximately 500 proteins were detected by ESI-TOF MS with the majority of proteins eluted at the $\mathrm{pI}$ range of 4.0-6.1. The vertical axis showed the $M_{\mathrm{r}}$ values of proteins in the range from 5 up to $95 \mathrm{kDa}$ based on
ESI-TOF MS analysis. A differential mass map was created by point-by-point subtraction to compare the protein expression of different samples. The actual resolution, relative quantification, and mass accuracy of specific protein bands were recovered from the original ESI-TOF MS data. Most of the proteins were similarly expressed at the two temperatures, which were referred to as housekeeping proteins. They are essential for the proper function of the bacterial cells during the cold adaptation process. In this study, we were most interested in the Caps that were preferentially or uniquely expressed at the low temperature. Using a relative abundance threshold of two, differentially expressed proteins were then identified by subsequent peptide mapping using MALDI-TOF MS and peptide sequencing with MALDI-QITTOF MS.

\subsection{Protein identification by PMF using MALDI-TOF MS}

Proteins eluted from HPLC were digested by trypsin and peptide mass maps were obtained using MALDI-TOF MS. The peptide masses were submitted to NCBInr by MS-Fit software for protein identification. The identification was based on the suggestion that at least five matched peptides with mass accuracy of $50 \mathrm{ppm}$ and sequence coverage of at least $20 \%$ [60]. Although this approach has been proven to be a successful means in protein identification, in practice, however, it is often difficult to obtain protein identification largely due to an insufficient number of detected peptides. Peptides were often prevented from being observed by weak response of lysine-terminated peptides, internal fragmentation, nonspecific and incomplete enzymatic digestion, and modification. In Table 1, the first 31 listed proteins were identified using the PMF method and had more than five theoretical tryptic peptides in the "working range" of MALDI-TOF MS with uracil phosphoribosyltransferase hav-

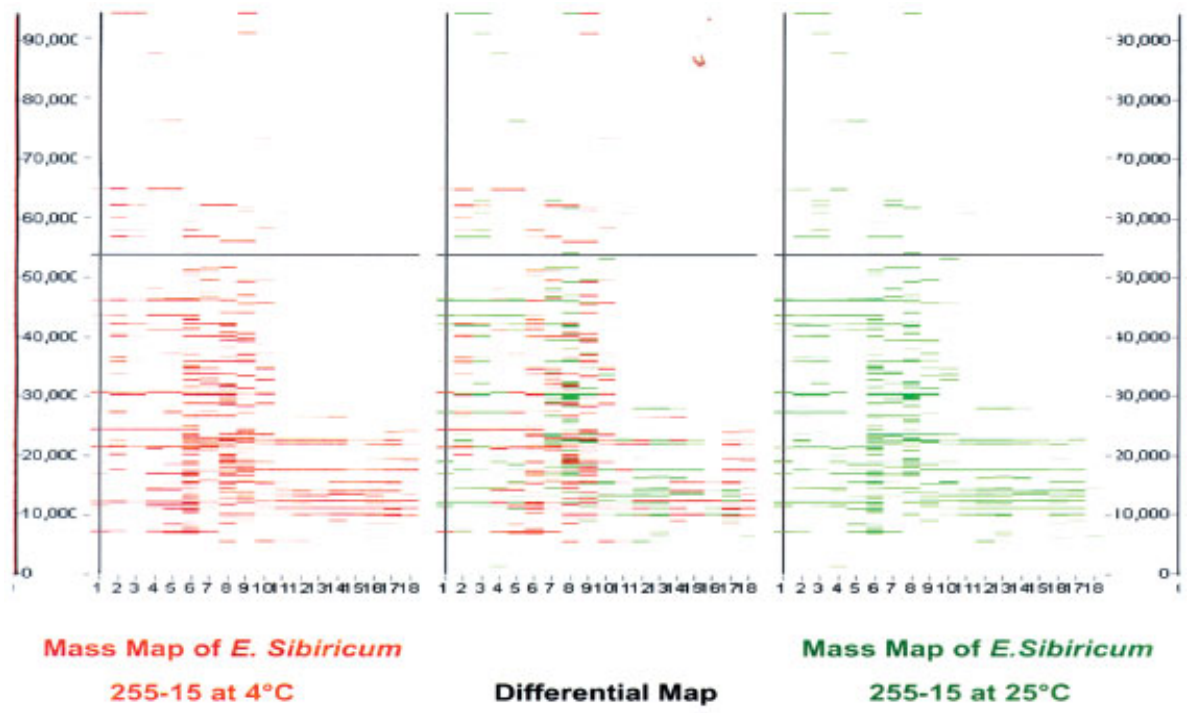

(C) 2006 WILEY-VCH Verlag GmbH \& Co. KGaA, Weinheim
Figure 1. Comparison of 2-D mass maps between E. sibiricum 255-15 grown at 4 and $25^{\circ} \mathrm{C}$. A 2-D mass map of $E$. sibiricum $255-15$ grown at $4^{\circ} \mathrm{C}$ is shown in shades of red on the left while protein expression of E. sibiricum 255-15 grown at $25^{\circ} \mathrm{C}$ is shown in shades of green on the right. The vertical axis shows the $M_{\mathrm{r}}$ values of proteins. The 18 lanes represent the $18 \mathrm{p} /$ fractions from CF separation. A differential mass map is shown in the middle in which the difference in protein expression between two growth temperatures is quantitatively plotted in shades of green and red. 
Table 1. Caps identified in E. sibiricum 255-15

\begin{tabular}{|c|c|c|c|c|c|c|c|}
\hline Protein ID (Accession No.) & $\begin{array}{l}\text { Experi- } \\
\text { mental } \\
\left(M_{\mathrm{r}}\right)\end{array}$ & $\begin{array}{l}\text { Experi- } \\
\text { mental } \\
(p /)\end{array}$ & $\begin{array}{l}\text { MOWSE } \\
\text { score }\end{array}$ & $\begin{array}{l}\text { Masses } \\
\text { matched }\end{array}$ & $\begin{array}{l}\% \text { Cover- } \\
\text { age }\end{array}$ & $\begin{array}{l}\text { Theoretical } \\
\left(M_{\mathrm{r}} / \mathrm{p} /\right)\end{array}$ & $\begin{array}{l}\text { Expression } \\
\text { ratio }^{\text {a) }}\end{array}$ \\
\hline $\begin{array}{l}\text { Enzyme related to GTP cyclohydrolase I } \\
\text { (45531353) }\end{array}$ & 19096 & $6.1-5.8$ & $6.88 \mathrm{E}+04$ & 8 & 57 & 19 095/5.2 & 3.803 \\
\hline $2^{\prime}-5^{\prime}-$ RNA ligase (46113530) & 19752 & $5.8-5.5$ & $1.76 \mathrm{E}+06$ & 10 & 74 & $19743 / 5.4$ & 2.986 \\
\hline $\begin{array}{l}\text { F0F1-type ATP synthase, subunit b } \\
\text { (45531034) }\end{array}$ & 20237 & $4.3-4.0$ & $4.38 \mathrm{E}+05$ & 11 & 47 & $20367 / 4.7$ & $N / A^{b)}$ \\
\hline $\begin{array}{l}\text { Uncharacterized conserved protein } \\
\text { (46113851) }\end{array}$ & 21810 & $6.7-6.4$ & $7.95 \mathrm{E}+04$ & 8 & 47 & $21941 / 6.4$ & 48.83 \\
\hline $\begin{array}{l}\text { Uracil phosphoribosyltransferase } \\
\text { (53771257) }\end{array}$ & 22910 & $5.8-5.5$ & $7.76 \mathrm{E}+09$ & 17 & 83 & $23043 / 5.5$ & 6.064 \\
\hline Hypothetical protein (45532138) & 23572 & $5.8-5.5$ & $1.53 \mathrm{E}+05$ & 6 & 48 & $23572 / 5.4$ & 2.503 \\
\hline $\begin{array}{l}\text { PspA (IM30), suppresss sigma 54-dependent } \\
\text { transcription (45532491) }\end{array}$ & 24464 & $4.9-4.6$ & $3.87 E+06$ & 18 & 53 & $24460 / 4.9$ & 74.09 \\
\hline Sporulation control protein (45530919) & 28742 & $5.5-5.2$ & $2.20 \mathrm{E}+04$ & 6 & 30 & $28739 / 5.0$ & $\mathrm{~N} / \mathrm{A}$ \\
\hline $\begin{array}{l}\text { Hydroxymethylpyrimidine/phospho- } \\
\text { methylpyrimidine kinase (46113160) }\end{array}$ & 28843 & $6.1-5.8$ & $6.42 \mathrm{E}+03$ & 6 & 29 & $28970 / 5.6$ & $\mathrm{~N} / \mathrm{A}$ \\
\hline Translation elongation factor Ts (45532587) & 31893 & $5.5-5.2$ & $8.62 \mathrm{E}+05$ & 8 & 39 & $31890 / 5.0$ & $\mathrm{~N} / \mathrm{A}$ \\
\hline $\begin{array}{l}\text { ABC-type uncharacterized transport system, } \\
\text { ATPase component (45530831) }\end{array}$ & 33396 & $5.8-5.5$ & $7.95 \mathrm{E}+05$ & 12 & 52 & $33397 / 5.6$ & 5.336 \\
\hline $\begin{array}{l}\text { NADPH/quinone reductase and related } \\
\text { Zn-dependent oxidoreductases (53771726) }\end{array}$ & 33826 & $5.2-4.6$ & $1.60 \mathrm{E}+04$ & 8 & 40 & $33826 / 4.8$ & $\mathrm{~N} / \mathrm{A}$ \\
\hline $\begin{array}{l}\text { Fructose-1,6-bisphosphatase/sedoheptulose } \\
\text { 1,7-bisphosphatase and related proteins } \\
(53771404)\end{array}$ & 33886 & $5.5-5.2$ & $9.66 \mathrm{E}+08$ & 15 & 61 & $33886 / 5.0$ & 7.187 \\
\hline $\begin{array}{l}\text { Predicted HD-superfamily hydrolase } \\
\quad(53771602)\end{array}$ & 34626 & $6.1-5.8$ & $1.45 \mathrm{E}+06$ & 8 & 32 & $34621 / 5.9$ & 25.68 \\
\hline Penicillin tolerance protein $(53771372)$ & 34706 & $6.1-5.8$ & $1.23 \mathrm{E}+06$ & 7 & 38 & $34703 / 5.7$ & 31.35 \\
\hline $\begin{array}{l}\text { Protoheme ferro-lyase (ferrochelatase) } \\
\quad(53771592)\end{array}$ & 34788 & $5.2-4.9$ & $5.26 \mathrm{E}+06$ & 9 & 35 & $34789 / 4.9$ & $\mathrm{~N} / \mathrm{A}$ \\
\hline $\begin{array}{l}\text { Glyceraldehyde-3-phosphate } \\
\text { dehydrogenase/erythrose-4-phosphate } \\
\text { dehydrogenase (46113193) }\end{array}$ & 35971 & $5.8-5.2$ & $4.72 \mathrm{E}+07$ & 13 & 33 & $36105 / 5.4$ & 3.126 \\
\hline Transcriptional regulators (46112980) & 37045 & $5.8-5.2$ & $5.31 E+04$ & 8 & 21 & $37047 / 5.4$ & 5.082 \\
\hline Cellulase $\mathrm{M}$ and related proteins (46113630) & 39295 & $5.8-5.2$ & $4.70 \mathrm{E}+04$ & 8 & 36 & $39298 / 5.3$ & 28.79 \\
\hline Alanine dehydrogenase (53771421) & 39670 & $5.8-5.2$ & $2.62 \mathrm{E}+05$ & 6 & 26 & $39672 / 5.2$ & $N / A$ \\
\hline $\begin{array}{l}\text { Pyruvate/2-oxoglutarate dehydrogenase } \\
\text { complex, dehydrogenase (E1) component, } \\
\text { eukaryotic type, alpha subunit (46113512) }\end{array}$ & 40141 & $5.2-4.6$ & $8.08 \mathrm{E}+05$ & 10 & 31 & $40137 / 5.1$ & 2.704 \\
\hline $\begin{array}{l}\text { 3-Oxoacyl-(acyl-carrier-protein) synthase } \\
\text { (46113125) }\end{array}$ & 44108 & $5.8-5.5$ & $6.47 \mathrm{E}+07$ & 9 & 37 & $44111 / 5.3$ & $\mathrm{~N} / \mathrm{A}$ \\
\hline $\begin{array}{l}\text { Uncharacterized conserved protein } \\
\text { (46113892) }\end{array}$ & 45624 & $5.8-5.5$ & $5.11 E+08$ & 13 & 44 & $45756 / 5.4$ & $\mathrm{~N} / \mathrm{A}$ \\
\hline $\begin{array}{l}\text { Glycine/serine hydroxymethyltransferase } \\
\text { (46113662) }\end{array}$ & 45723 & $6.1-5.8$ & $8.23 E+07$ & 16 & 41 & $45716 / 5.7$ & 2.279 \\
\hline $\begin{array}{l}\text { Glutamate-1-semialdehyde aminotrans- } \\
\text { ferase }(46113490)\end{array}$ & 46903 & $5.8-5.5$ & $2.84 \mathrm{E}+05$ & 8 & 33 & $47038 / 5.4$ & $\mathrm{~N} / \mathrm{A}$ \\
\hline Predicted GTPase (46113059) & 47472 & $5.2-4.9$ & $3.61 \mathrm{E}+04$ & 11 & 37 & $47488 / 5.2$ & $N / A$ \\
\hline
\end{tabular}


Table 1. Continued

\begin{tabular}{|c|c|c|c|c|c|c|c|}
\hline Protein ID (Accession No.) & $\begin{array}{l}\text { Experi- } \\
\text { mental } \\
\left(M_{\mathrm{r}}\right)\end{array}$ & $\begin{array}{l}\text { Experi- } \\
\text { mental } \\
(\mathrm{p} /)\end{array}$ & $\begin{array}{l}\text { MOWSE } \\
\text { score }\end{array}$ & $\begin{array}{l}\text { Masses } \\
\text { matched }\end{array}$ & $\begin{array}{l}\% \text { Cover- } \\
\text { age }\end{array}$ & $\begin{array}{l}\text { Theoretical } \\
\left(M_{\mathrm{r}} / \mathrm{p} /\right)\end{array}$ & $\begin{array}{l}\text { Expression } \\
\text { ratio }^{\text {a) }}\end{array}$ \\
\hline $\begin{array}{l}\text { FKBP-type peptidyl-prolyl cis-trans } \\
\text { isomerase (TF) }(46113050)\end{array}$ & 48029 & $4.3-4.0$ & $3.98 E+06$ & 9 & 29 & $48026 / 4.3$ & 4.094 \\
\hline $\begin{array}{l}\text { Thiamine pyrophosphate-requiring enzymes } \\
\text { (acetolactate synthase, pyruvate dehydro- } \\
\text { genase (cytochrome), glyoxylate carbo- } \\
\text { ligase, phosphonopyruvate decarboxylase) } \\
\text { (46113116) }\end{array}$ & 61994 & $5.2-4.9$ & $1.11 \mathrm{E}+10$ & 19 & 46 & $61988 / 5.2$ & 3.082 \\
\hline Hsp70 Molecular chaperone (45531750) & 64781 & $<4.0$ & $1.20 \mathrm{E}+04$ & 7 & 25 & $64904 / 4.6$ & 2.815 \\
\hline $\begin{array}{l}\text { ATPases with chaperone activity, } \\
\text { ATP-binding subunit (46113174) }\end{array}$ & 90678 & $5.8-5.5$ & $9.70 E+09$ & 18 & 34 & $90773 / 5.8$ & 2.384 \\
\hline $\begin{array}{l}\text { Uncharacterized protein conserved in } \\
\text { bacteria }(46112941)\end{array}$ & 13364 & $5.8-5.5$ & $8.55 E+03$ & 3 & 54 & $13332 / 5.3$ & 2.941 \\
\hline $\begin{array}{l}\text { Chromosome segregation ATPase } \\
\text { (45532021) }\end{array}$ & 19304 & $5.5-5.2$ & $6.23 E+02$ & 3 & 24 & $19301 / 5.0$ & $N / A$ \\
\hline $\begin{array}{l}\text { DNA-directed RNA polymerase specialized } \\
\text { sigma subunit, sigma24 homolog } \\
\text { (46113445) }\end{array}$ & 21365 & $5.5-5.2$ & $7.26 \mathrm{E}+02$ & 4 & 36 & $21363 / 5.4$ & $\mathrm{~N} / \mathrm{A}$ \\
\hline $\begin{array}{l}\text { Dehydrogenases with different specificities } \\
\quad(46113222)\end{array}$ & 23028 & $5.8-5.5$ & $1.39 E+02$ & 4 & 17 & $23028 / 5.3$ & 23.72 \\
\hline $\begin{array}{l}\text { Alpha-acetolactate decarboxylase } \\
\quad(45531272)\end{array}$ & 26705 & $5.2-4.9$ & $1.49 E+03$ & 4 & 31 & $26704 / 5.0$ & 28.02 \\
\hline Triosephosphate isomerase (46113191) & 26825 & $5.2-4.9$ & $1.49 \mathrm{E}+03$ & 4 & 25 & $26827 / 4.9$ & 3.171 \\
\hline Lysophospholipase (53771292) & 27078 & $5.8-5.5$ & $1.79 \mathrm{E}+03$ & 4 & 26 & $27079 / 5.9$ & $\mathrm{~N} / \mathrm{A}$ \\
\hline $\begin{array}{l}\text { Predicted sugar phosphate isomerase } \\
\quad(46114194)\end{array}$ & 31763 & $5.5-5.2$ & $6.65 E+02$ & 4 & 20 & $31767 / 5.2$ & $\mathrm{~N} / \mathrm{A}$ \\
\hline $\begin{array}{l}\text { Uncharacterized conserved protein } \\
\text { (46114036) }\end{array}$ & 33644 & $4.9-4.6$ & $3.88 \mathrm{E}+02$ & 4 & 20 & $33640 / 4.8$ & $N / A$ \\
\hline
\end{tabular}

a) Protein quantification was based on its peak area from ESI-TOF MS analysis. Expression ratios were obtained by dividing the amount of protein expressed at $4^{\circ} \mathrm{C}$ with the amount of the same protein expressed at $25^{\circ} \mathrm{C}$.

b) The expression ratios of the proteins that were exclusively expressed at $4^{\circ} \mathrm{C}$ were not available (N/A) in the table.

ing the highest sequencing coverage of $83 \%$. All identities were confirmed by intact $M_{\mathrm{r}}$ values from online NPS-RPHPLC/ESI-TOF MS experiments. In contrast, the last 11 proteins in the table were not identified with $\leq 4$ peptides detected, which did not meet the requirement for protein identification by the PMF method and thus need to be sequenced by MS/MS for identification. Although these proteins could not be identified using the PMF method, peptide maps from MALDI-TOF MS provided very important information of potential interesting peptides for further sequencing using MALDI-QIT-TOF MS.

The intact $M_{\mathrm{r}}$ is extremely important in terms of protein identification using peptide mapping and peptide sequencing. With the use of an accurate $M_{\mathrm{r}}$ one can find the potential protein ID among several possibilities in protein database searching. Also, there are often isoforms and truncated forms of proteins and the $M_{\mathrm{r}}$ provides confidence as to which form is being studied. In addition, there may be several proteins that are of similar $M_{\mathrm{r}}$ and difficult to distinguish; however, with the use of accurate $M_{\mathrm{r}}$ measurements one can readily identify the presence of these proteins [57]. The discrepancy between the experimental and the theoretical $M_{\mathrm{r}}$ values in Table 1 may result from as yet unidentified PTMs or protein truncation. There is an $M_{\mathrm{r}}$ associated with each protein identified in this work.

\subsection{Protein identification by peptide sequencing using MALDI-QIT-TOF MS}

Another protein identification method is based on peptide sequencing using peptide CID spectra. CID amide bond fragmentation along the length of the peptide generates $b$ - 
and $\gamma$-ions, which reveal the peptide sequence. Protein identification is obtained by searching the protein database with the detected fragment ions in the experiment. The MALDIQIT-TOF MS used in the work provides high sensitivity and resolution as well as the advantage of sharing the same sample preparation procedure with MALDI-TOF MS. Proteins analyzed by MALDI-TOF MS can be reanalyzed by MALDI-QIT-TOF MS after placing a new sample spot on the MALDI-QIT-TOF plate. The quality of MS/MS data and the effectiveness of using MALDI-QIT-TOF MS in protein identification have been discussed [61-63].

Protein identification by peptide sequencing is more reliable than that achieved by PMF and may allow the identification of proteins based on a single peptide fragmentation sequence [51]. The major advantage of this method is that the small proteins that are difficult to identify by PMF due to an insufficient number of detected peptides may be identified using peptide sequencing if the peptide signal and its fragment signals are of sufficient intensity. In the case of $7.150 \mathrm{kDa}$ Csp, only one peptide with $M_{\mathrm{r}}$ of 1098 was detected by MALDI-TOF MS. The peptide was then subjected to MALDI-QIT-TOF sequencing and the resulting CID spectrum in Fig. 2 shows $b$ - and $\gamma$-ions with rich sequence information. When the parent ion and product ions were used to search against NCBInr using MASCOT software, a $7.150 \mathrm{kDa}$ Csp was identified with the corresponding peptide sequence comprising amino acids 40-56. Its identity was confirmed by an accurate $M_{\mathrm{r}}$ measurement in Fig. 3 in which two of the multiple-charged-ion umbrellas of ESI-TOF spectra were as shown in Fig. 3A and B and the intact $M_{\mathrm{r}}$ values obtained by deconvoluting Fig. 3A and B into a MaxEnt spectrum on a real-mass scale are shown in Fig. $3 \mathrm{C}$ and D. In this case, proteins of 7.150 and $7.414 \mathrm{kDa}$ coeluted at both $4^{\circ} \mathrm{C}$ and $25^{\circ} \mathrm{C}$, while a protein of $7.444 \mathrm{kDa}$ was expressed only at $4^{\circ} \mathrm{C}$. In order to identify these proteins, the tryptic digests of the RPLC fraction that contain all these proteins were peptide mapped by MALDI-TOF MS (Fig. 4), and each of the detected peptides was then subjected to MALDI-QIT sequencing. Two possible homologous Csps with the same molecular mass of $7.409 \mathrm{kDa}$ but slightly different $\mathrm{pH}$ values of 4.55 and 4.41 were detected by MALDI-QIT-TOF sequencing when the peptide 1937 (SLDEGQEVSFEVEEGQR) was submitted for CID fragmentation as show in Fig. 5. Identities of both proteins were confirmed with the fragmentation of peptide 2098 (ESGDDVFVHFSAIQTDGFK) (Fig. 6) and 2125 (ENGDDVFVHFSAIQTDGFK) (Fig. 7), which were also reconfirmed by the accurate $M_{\mathrm{r}}$ measurement as shown in Fig. 3. Using peptide sequencing by MALDI-QIT-TOF MS, all the proteins not identified by PMF in Table 1 were identified.

\subsection{Homologous Csps}

The three Csps discussed above have similar $M_{\mathrm{r}}, \mathrm{p} I$, and amino acid sequence with $65.15,66.67$, and $59.09 \%$ overlap with the sequence of major CspA in E. coli and over 74\% when compared to $C s p B, C s p C$, and $C s p D$ in $B$. subtilis (Table 2), which suggests that these three Csps are the major homologous Csps in E. sibiricum 255-15. An interesting finding in this study is that, unlike in E. coli and B. subtilis, the three Csp family homologous proteins were found similarly expressed at $25^{\circ} \mathrm{C}$ and $4^{\circ} \mathrm{C}$ based on ESI-TOF MS analysis. In fact, the three Csps represent about $10 \%$ of the total soluble proteins in cells grown at both $4^{\circ} \mathrm{C}$ and $25^{\circ} \mathrm{C}$. This result suggests that the genes for these proteins are turned on continuously to produce proteins to protect the cells from cold damage. Such behavior has been observed in other extremophiles such as psychrobacter where it has been shown in gene expression array studies that certain genes are always expressed. Apparently, these organisms which survive for long periods of time under cold conditions have adapted such a continuous expression as a means of survival [64].

\subsection{Caps}

\subsubsection{Caps characterized as Csps in E. coli}

From peptide mapping and peptide sequencing analysis, 39 identified proteins with $M_{\mathrm{r}}$ ranging from 7 to $95 \mathrm{kDa}$ presented an increased level of synthesis at the lower tempera-

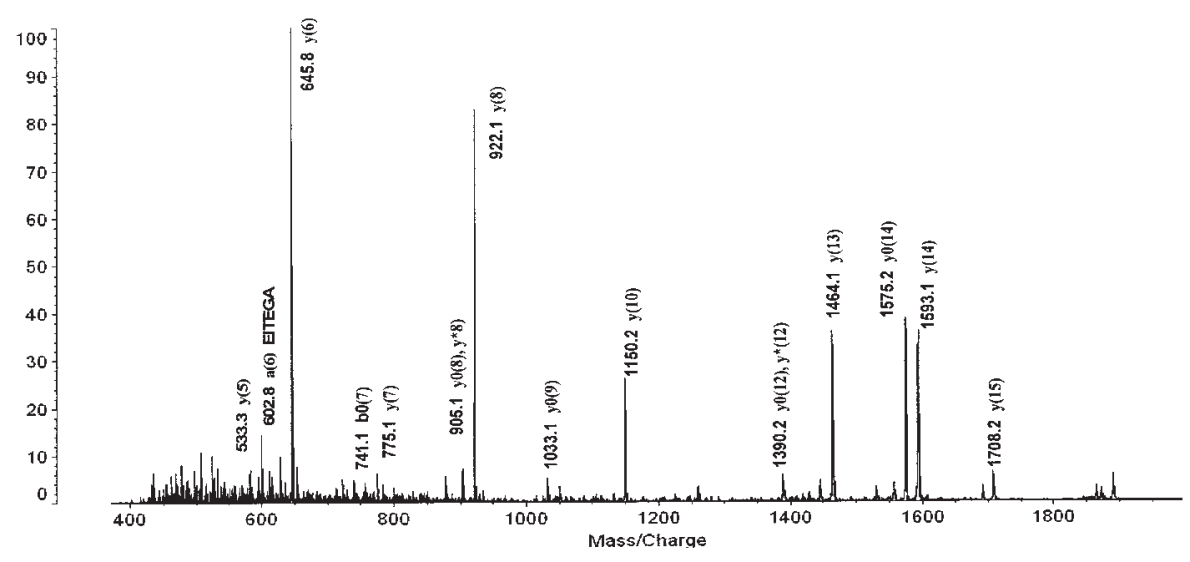

Figure 2. MALDI-OIT-TOF peptide sequencing of 1098.7 (SLDEGQEVEFEITEGAR) from Csp (7.150 kDa, pH 4.54). In this case, $y^{*}(i)=y(i)-\mathrm{NH}_{3}, \quad y 0(i)=$ $y(\mathrm{i})-\mathrm{H}_{2} \mathrm{O}$ and $\mathrm{bO}(\mathrm{i})=\mathrm{b}(\mathrm{i})-\mathrm{H}_{2} \mathrm{O}$. 


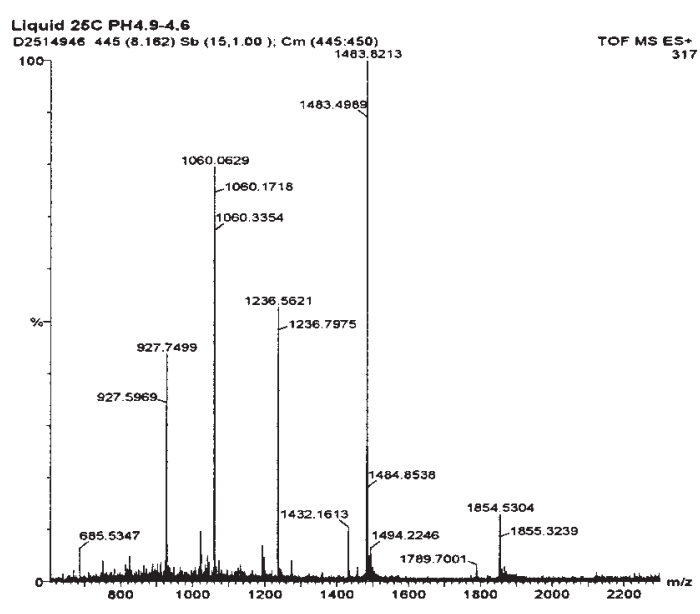

A

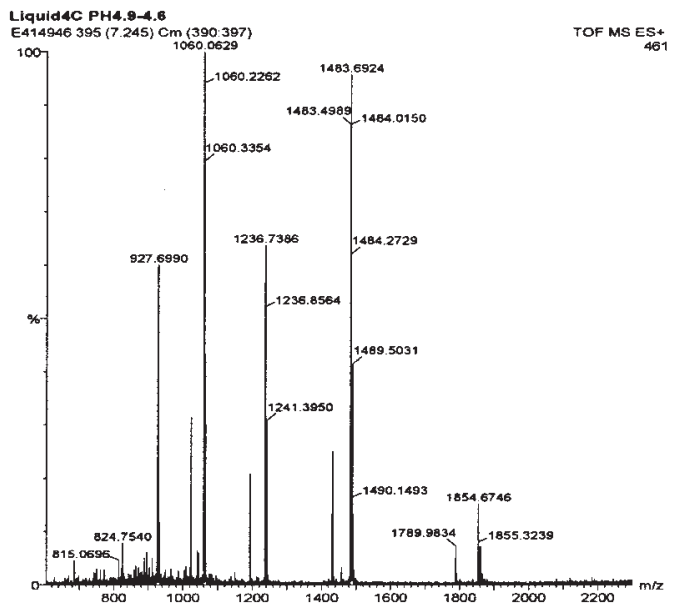

B

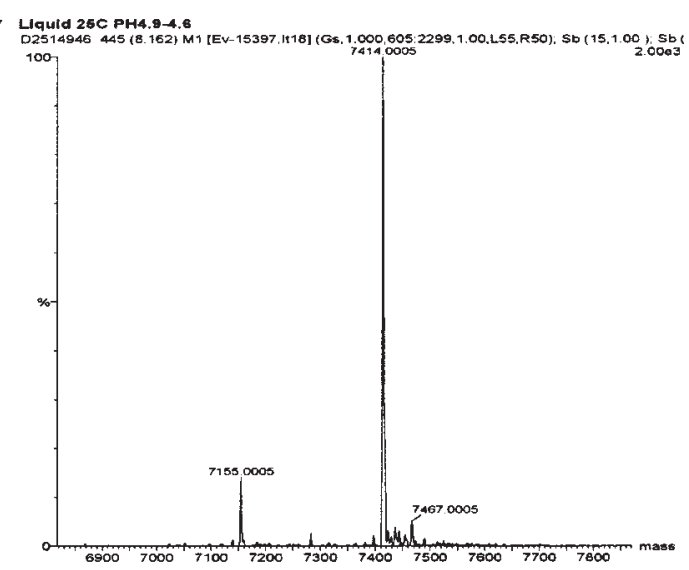

$\mathrm{C}$

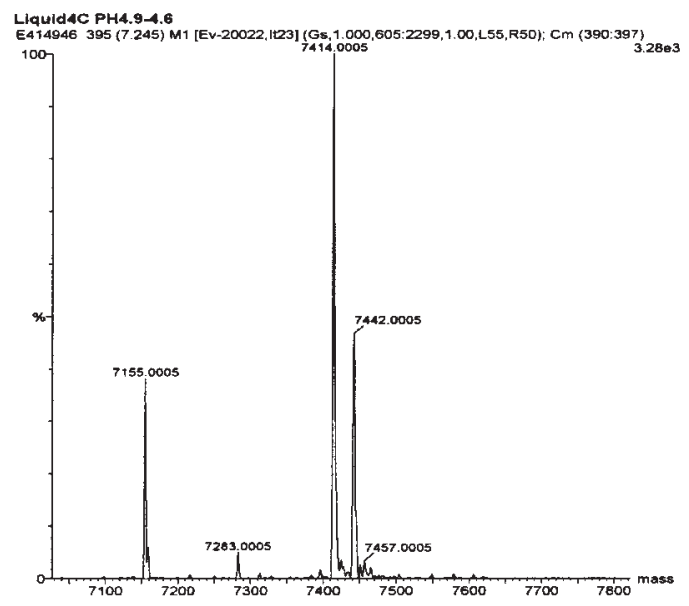

$\mathrm{D}$

Figure 3. ESI-TOF spectra of an NPS-RP-HPLC fraction containing 7.150 and $7.414 \mathrm{kDa}$ Csps at $25^{\circ} \mathrm{C}(\mathrm{A})$ and its corresponding HPLC fraction at $4^{\circ} \mathrm{C}(\mathrm{B})$. Their deconvoluted spectra are shown in (C) and (D). A protein of $7.442 \mathrm{kDa}$ was exclusively expressed at $4^{\circ} \mathrm{C}$ as shown in (D).

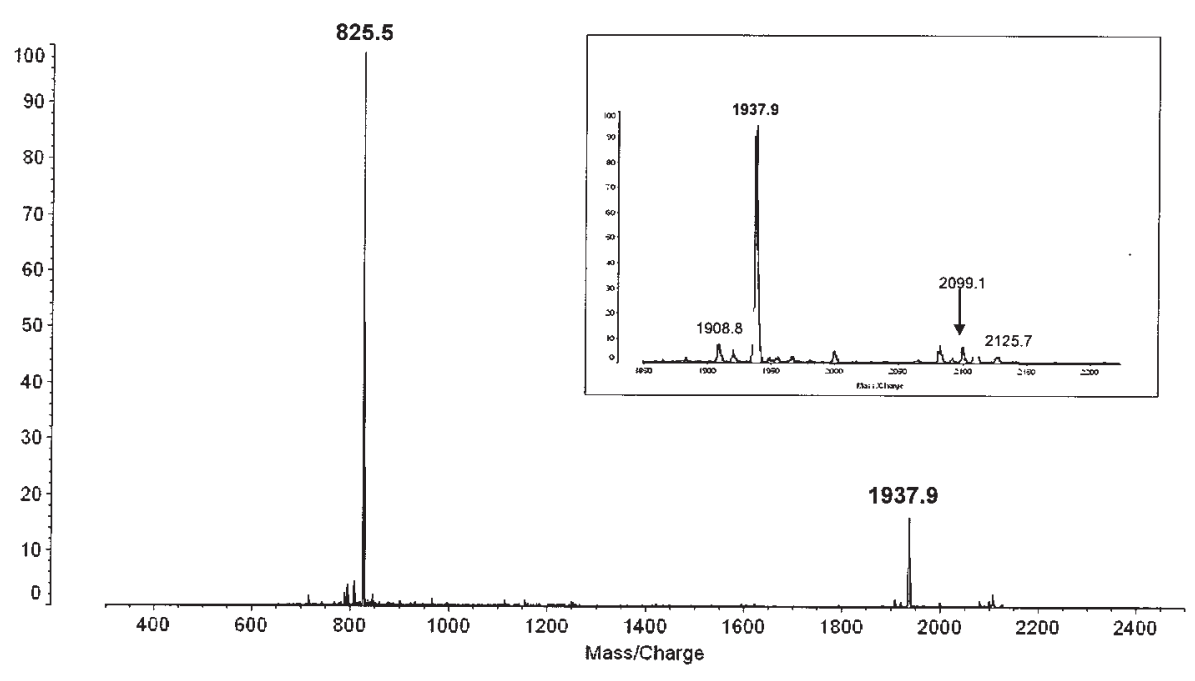

Figure 4. MALDI-TOF peptide mapping of NPS-RP-HPLC fraction containing proteins of $7.150,7.414$, and $7.444 \mathrm{kDa}$. 


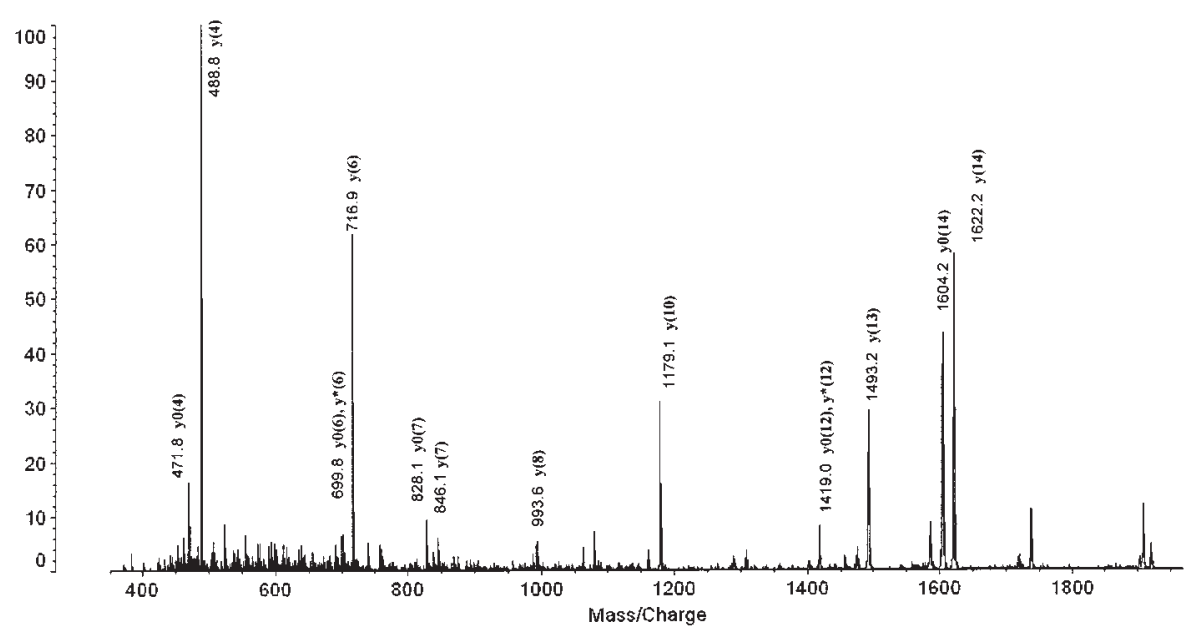

Figure 5. MALDI-OIT-TOF peptide sequencing of 1937.9 (SLDEGQEVSFEVEEGQR) from homologous Csps of $7.409 \mathrm{kDa}$ (pH 4.55) and 7.409 kDa (pH 4.41).

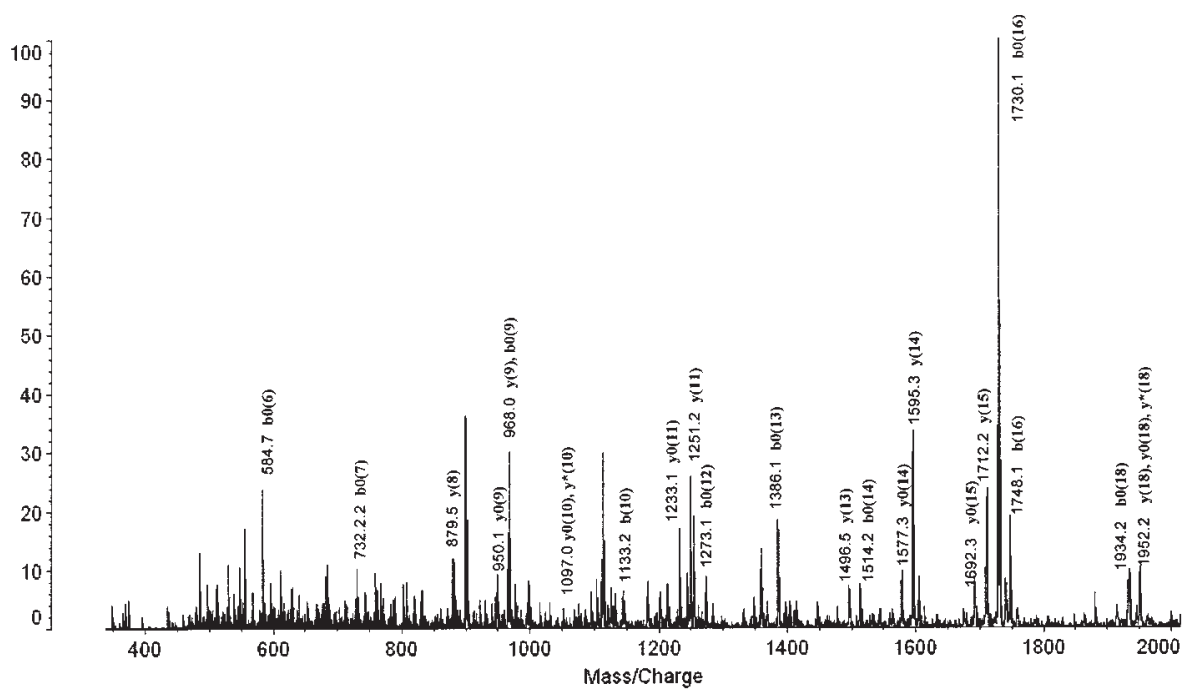

Figure 6. MALDI-OIT-TOF peptide sequencing of 2098.0 (ESGDDVFVHFSAIQTDGFK) from Csp (7.409 kDa, pH 4.55).

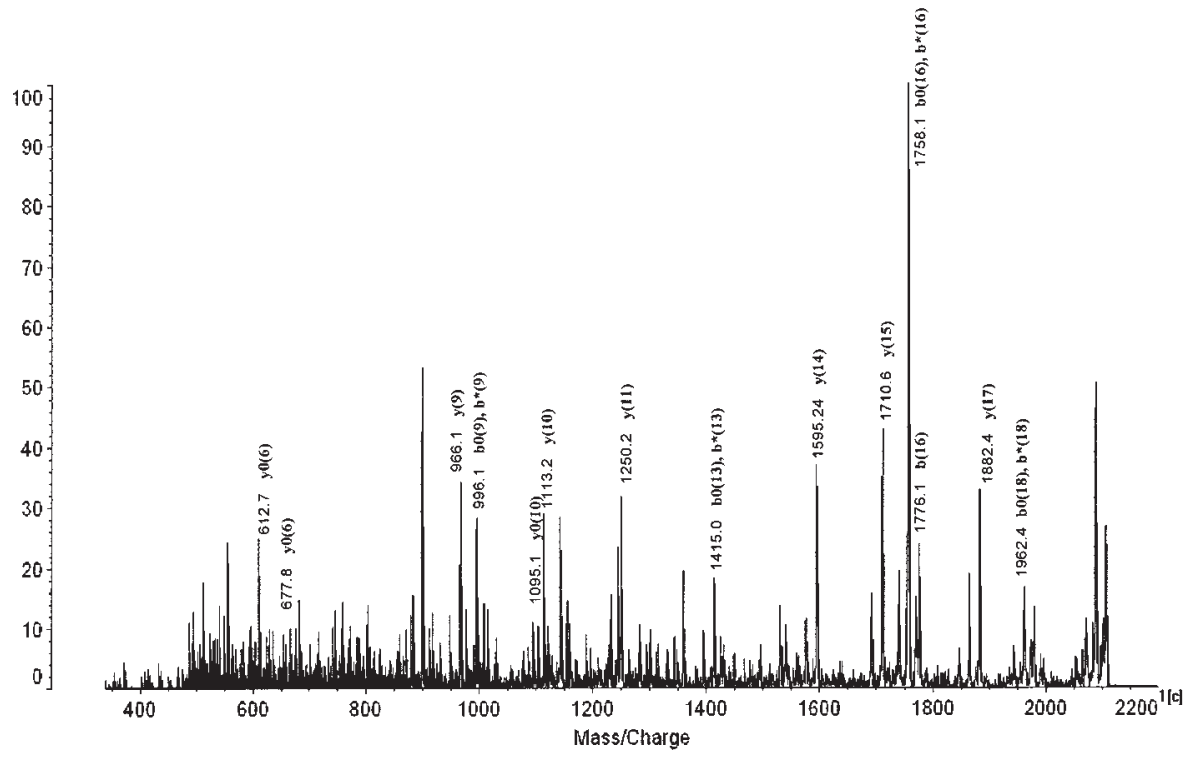

Figure 7. MALDI-OIT-TOF peptide sequencing of 2125.1 (ENGDDVFVHFSAIQTDGFK) from Csp (7.409 kDa, $\mathrm{pH}$ 4.41). In this case, $b^{*}(i)=b(i)-\mathrm{NH}_{3}$. 
Table 2. Sequence alignment of the homologous Csps in E. sibiricum 255-15

\begin{tabular}{|c|c|c|}
\hline CspA in E. coli & $\begin{array}{l}\text { MTQGTVKWFN SEKGFGFISS ETGTDVFAHF SEIKVDGFKT LEEGQKVTFD } \\
\text { IODGQRGPQA TNINLVK }\end{array}$ & Identity (\%) \\
\hline 7.409 kDa Csp (pH 4.55) & 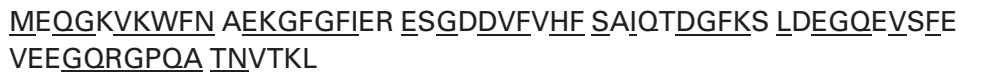 & 65.15 \\
\hline 7.409 kDa Csp (pH 4.41) & 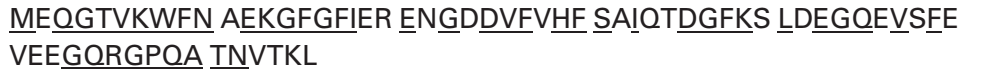 & 66.67 \\
\hline $7.150 \mathrm{kDa}$ Csp (pH 4.54) & 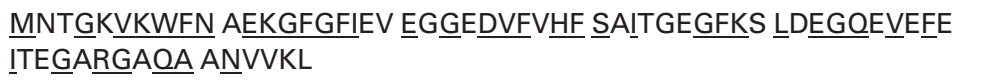 & 59.09 \\
\hline CspB in B. subtilis & $\begin{array}{l}\text { MLEGKVKWFN SEKGFGFIEV EGQDDVFVHF SAIQGEGFKT LEEGQAVSFE } \\
\text { IVEGNRGPQA ANVTKEA }\end{array}$ & Identity (\%) \\
\hline 7.409 kDa Csp (pH 4.55) & 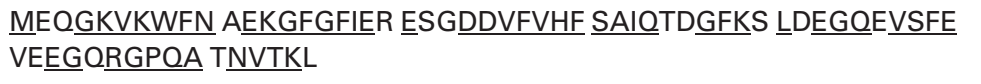 & 75.76 \\
\hline $7.409 \mathrm{kDa}$ Csp (pH 4.41) & 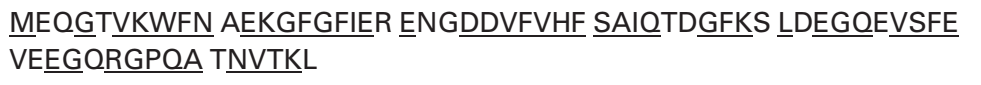 & 74.24 \\
\hline $7.150 \mathrm{kDa}$ Csp (pH 4.54) & 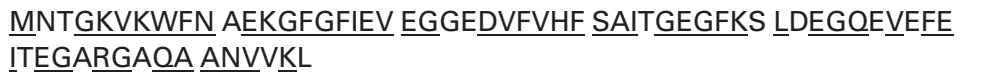 & 77.27 \\
\hline CspC in B. subtilis & $\begin{array}{l}\text { MEQGTVKWFN AEKGFGFIER ENGDDVFVHF SAIQSDGFKS LDEGQKVSFD } \\
\text { VEQGARGAQA ANVQKA }\end{array}$ & Identity (\%) \\
\hline 7.409 kDa Csp (pH 4.55) & 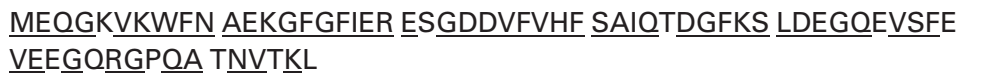 & 83.33 \\
\hline $7.409 \mathrm{kDa} \operatorname{Csp}(\mathrm{pH} 4.41)$ & 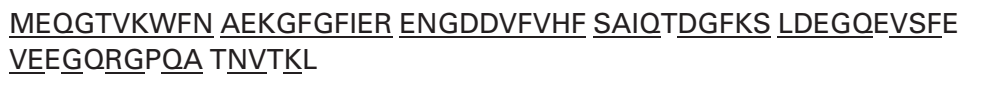 & 86.38 \\
\hline $7.150 \mathrm{kDa}$ Csp (pH 4.54) & 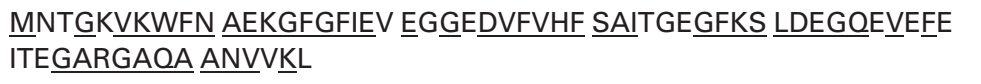 & 74.24 \\
\hline CspD in B. subtilis & $\begin{array}{l}\text { MQNGKVKWFN NEKGFGFIEV EGGDDVFVHF TAIEGDGYKS LEEGQEVSFE } \\
\text { IVEGNRGPQA SNVVKL }\end{array}$ & Identity (\%) \\
\hline 7.409 kDa Csp (pH 4.55) & 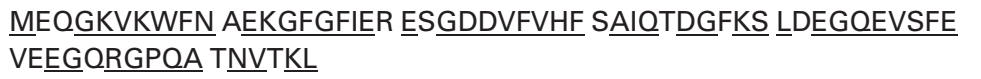 & 78.79 \\
\hline $7.409 \mathrm{kDa}$ Csp (pH 4.41) & 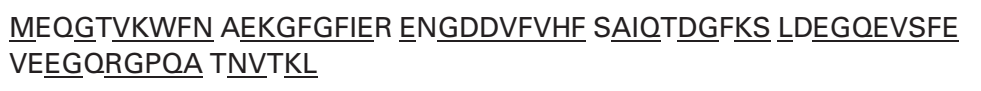 & 77.27 \\
\hline $7.150 \mathrm{kDa} \operatorname{Csp}(\mathrm{pH} 4.54)$ & 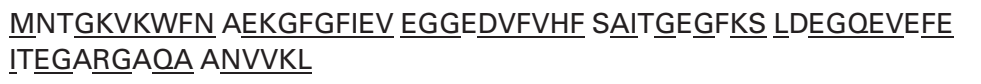 & 78.79 \\
\hline
\end{tabular}

a) $C s p A$ in E. coli, $C s p B, C s p C$, and $C s p D$ in $B$. subtilis are the reference molecules for this sequence alignment. b) The identical residues are underlined.

ture and were considered to be Caps, 16 of which were not detected at $25^{\circ} \mathrm{C}$. Some of these Caps were characterized as Csps in E. coli, such as trigger factor (TF) and pyruvate dehydrogenase. TF is a molecular chaperone with prolyl isomerase activity that may be a bottleneck in the folding of some polypeptides at low temperature. TF can be crosslinked to the nascent polypeptide chain on the ribosome and binds to the GroEL chaperone. This TF enhances the affinity of GroEL toward unfolding proteins and activates the degradation of some polypeptides [65-67]. Unlike the TF, the role of pyruvate dehydrogenase has not yet been well understood. Presumably, they are involved in the intensification of glycolysis and the suppression of the tricarboxylic acid cycle, i.e., in the processes that are observed upon the retardation of cell growth, and the adaptation of cells to stresses [12, 68, 69].

\subsubsection{Caps characterized as other stress-induced proteins}

Like in E. coli, the overexpression of heat shock protein 70 (Hsp70) molecular chaperones was also observed in E. sibiricum 255-15 during the cold adaptation process. Most heat shock proteins may function as molecular chaperones that play an important role in protein folding. It seems that folding of exiguobacterial proteins at near-freezing temperatures is also jeopardized and, therefore, Hsp70 and other heat shock proteins are required. Thus, these so-called "heat shock proteins" are not simply heat shock-specific proteins. They should more appropriately be called "temperaturestress proteins." Hsp molecular chaperones were found to be actively synthesized in response to heat, cold, and chemical 
stress [70]. Based on the 2-D mass map analysis, phage shock protein A (PspA) was the most differentially expressed protein at different growth temperatures whose expression ratio was over 70. Presently, the exact function of PspA remains elusive. Various stress conditions, including severe heat shock, cold shock, osmotic shock, and exposure to ethanol [71-73], which is involved in protein translation across the cytoplasmic membrane, have been reported to induce expression of the Psp operon. These stress conditions might all lead to the dissipation of the proton-motive force, and it has been demonstrated that expression of the Psp operon, and more specifically of PspA, helps the cells to maintain the proton-motive force under such stress conditions [74]. Penicillin tolerance protein was also found greatly overexpressed at $4^{\circ} \mathrm{C}$. These facts suggest that a single stress could induce other stress-induced proteins that are organized in a complex and highly sophisticated adaptation network.

\subsubsection{Enzymes}

E. sibiricum $255-15$ is able to grow efficiently at near-freezing temperatures. Clearly, this organism has found mechanisms of temperature compensation in order to cope with the reduction of chemical reaction rates induced by low temperatures. Synthesizing more enzymes and synthesizing cold-efficient enzymes are two possible means for adaptation [75]. Adjustment of enzyme concentration has been reported during cold adaptation. For instance, increased expression of polynucleotide phosphorylase has been detected in E. coli at low temperatures [76]. Another mechanism for survival is to possess enzymes with temperature-independent reaction rates. This is the case of perfectly evolved enzymes, however such enzymes are relatively rare: typical examples are carbonic anhydrase, acetylcholinesterase, and triosephosphate isomerase. In this study, the higher level of triosephosphate isomerase has been detected in a cold adapted population of E. sibiricum 255-15. Perfectly evolved enzymes could be extremely useful to probe the various hypotheses related to enzyme adaptation because, apparently, they do not need to be adapted to low temperatures from a kinetic point of view. In this study, 28 out of 39 identified Caps are enzymes. Although the roles of these enzymes concerning how they interact together to maintain the adequate metabolic fluxes need to be further studied, it is possible that these enzymes maintain the bacterial metabolism enabling the cells to adapt to cold temperatures.

\subsubsection{Possible PTM}

From ESI-TOF MS measurement in Fig. 3, a protein of $7.442 \mathrm{kDa}$ coeluted with the three homologous Csps at $4^{\circ} \mathrm{C}$, which suggests that this $7.442 \mathrm{kDa}$ protein might play an important role in the physiology of the cells during cold adaptation. From the peptide map obtained from MALDITOF MS analysis in Fig. 4, there were no detected peptides that could be assigned to a protein other than the three co- eluted Csps. Based on the mass difference of this protein and the three identified Csps, this protein may be another homologous Csp with the above three or be a post-translationally modified Csp that was induced during the cold adaptation process.

\section{Concluding remarks}

At the proteomic level, 2-D liquid separation coupled with ESI-TOF MS, MALDI-TOF MS, and MALDI-QIT-TOF MS provides rapid, accurate, and reproducible protein fractionation and identification in the study of cold adaptation in $E$. sibiricum 255-15. The accurate $M_{\mathrm{r}}$ of protein from ESI-TOF MS, together with the $\mathrm{p} I$ from $\mathrm{CF}$, is essential for protein identification and characterization.

The results from this study indicated that the adaptive nature of E. sibiricum 255-15 at near-freezing temperatures could be regulated by cellular physiological processes through the regulation of certain cellular proteins. Although the cold adaptation is still far from being properly understood, it is possible that new and increasingly synthesized proteins at the low temperature may support temperature homeostasis and enable the cells to adapt to the near or below-freezing temperatures. Chaperone proteins could be involved in the protection of proteins from denaturation and damage when E. sibiricum 255-15 cultures were exposed to cold temperature. Moreover, the unique nature of these proteins, differing from previously reported Csps, also warrants further enquiry.

This work was supported by National Aeronautics and Space Administration (NASA) Astrobiology Institute under cooperative agreement no. CAN-00-OSS-01 issued through the Office of Space Science. We thank Weilian Qiu for assistance in the protein preconcentration procedure.

\section{References}

[1] Gilichinsky, D., in: Bitton, G. (Ed.), Encyclopedia of Environmental Microbiology, Wiley, New York 2002, pp. 932-956.

[2] Abyzov, S., in: Friedmann, E. I. (Ed.), Antarctic Microbiology, Wiley, New York 1993, pp. 265-297.

[3] Cano, R., Borucki, M., Science 1995, 268, 1060-1064.

[4] Lipman, C., Science 1928, 68, 272-273.

[5] Vreeland, R., Rosenzweig, W., Powers, D., Nature 2000, 407, 897-900.

[6] Jones, P. G., VanBogelen, R. A., Neidhardt, F. C., J. Bacteriol. 1987, 169, 2092-2095.

[7] Goldstein, J., Pollitt, N. S., Inouye, M., Proc. Natl. Acad. Sci USA 1990, 87, 283-287.

[8] Lee, S. J., Xie., A., Jiang, W., Etchegaray, J. P. et al., Mol. Microbiol. 1994, 11, 833-839. 
[9] Nakashima, K., Kanamaru, K., Mizuno, T., Horikoshi, K., J. Bacteriol. 1996, 178, 2994-2997.

[10] Wang, N., Yamanaka, K., Inouye, M., J. Bacteriol. 1999, 181, 1603-1609.

[11] Lelivelt, M. J., Kawula, T. H., J. Bacteriol. 1995, 177, 49004907.

[12] Graumann, P., Marahiel, M. A., Arch. Microbiol. 1996, 166, 293-300.

[13] Jones, P. G., Krah, R., Tafuri, S. R., Wolffe, A. P., J. Bacteriol. 1992, 174, 5798-5802.

[14] Yamanaka, K., Fang, L., Inouye, M., Mol. Microbiol. 1998, 27, 247-255.

[15] Jiang, W., Hou, Y., Inouye, M., J. Biol. Chem. 1997, 272, 196202.

[16] Kandror, O., Goldberg, A. L., Proc. Natl. Acad. Sci USA 1997, 94, 4978-4981.

[17] Brandi, A., Pietroni, P., Gualerzi, C. O., Pon, C. L., Mol. Microbiol. 1996, 19, 231-240.

[18] Goldberg, D., Azar, I., Oppenheim, A. B., Mol. Microbiol. 1996, 19, 241-248.

[19] Aguilar, P. S., Cronan, J. E., de Mendoza, D., J. Bacteriol. $1998,180,2194-2200$.

[20] Graumann, P. L., Marahiel, M. A., Arch. Microbiol. 1999, 171, 135-138.

[21] Schroder, K., Zuber, P., Willimsky, G., Wagner, B., Marahiel, M. A., Gene 1993, 136, 277-280.

[22] Willimsky, G., Bang, H., Fischer, G., Marahiel, M. A., J. Bacteriol. 1992, 174, 6326-6335.

[23] Graumann, P., Schroder, K., Schmid, R., Marahiel, M. A., J. Bacteriol. 1996, 178, 4611-4619.

[24] Graumann, P., Marahiel, M. A., FEBS Lett. 1994, 338, 157160.

[25] Schnuchel, A., Wiltscheck, R., Czisch, M., Herrler, M. et al., Nature 1993, 364, 169-171.

[26] Schindelin, H., Marahiel, M. A., Heinemann, U., Nature 1993, 364, 164-168.

[27] Schindler, T., Perl, D., Graumann, P., Sieber, V. et al., Proteins 1998, 30, 401-406.

[28] Graumann, P., Wendrich, T. M., Weber, M. H., Schroder, K. Marahiel, M. A., Mol. Microbiol. 1997, 25, 741-756.

[29] Graumann, P., Marahiel, M. A., Mol. Gen. Genet. 1997, 253, 745-752.

[30] Schindler, T., Graumann, P. L., Perl, D., Ma, S. et al., J. Biol. Chem. 1999, 274, 3407-3413.

[31] Mayr, B., kaplan, T., Lechner, S., Scherer, S., J. Bacteriol. 1996, 178, 2916-2925.

[32] Whyte, L. G., Inniss, W. E., Can. J. Microbiol. 1992, 38, 12811285.

[33] Berger, F., Normand, P., Potier, P., J. Bacteriol. 1997, 179, 5670-5676.

[34] Berger, F., Morellet, N., Menu, F., Potier, P., J. Bacteriol. 1996, 178, 2999-3007.

[35] Panoff, J. M., Corroler, D., Thammaavongs, B., Boutibonnes, P., J. Bacteriol. 1997, 179, 4451-4454.
[36] Baylee, D. O., Annous, B. A., Wilkinson, B. J., Appl. Environ. Microbiol. 1996, 62, 1116-1119.

[37] Hebraud, M., Guzzo, J., FEMS Mcirobiol. Lett. 2000, 190, 29 34.

[38] Wemekamp-Kamphuis, H. H., Karatzas, A. K., Wouters, J. A., Abee, T., Appl. Environ. Microbiol. 2002, 62, 456-463.

[39] Manganelli, R., Dubanu, E., Tyagi, S., Kramer, F. R., Smith, I., Mol. Microbiol. 1999, 31, 715-724.

[40] Hebraud, M., Dubois, E., Potier, P., Labadie, J., J. Bacteriol. $1994,176,4017-4024$

[41] Michel, V., Lethoux, I., Depret, G., Anglade, P. et al., J. Bacteriol. 1997, 179, 7331-7342.

[42] Michel, V., Labadie, J., Hebraud, M., Curr. Microbiol. 1996, $33,16-25$.

[43] Smith, C. M., Koch, W. H., Franklin, S. B., Foster, P. L. et al., J. Bacteriol. 1990, 172, 4964-4978.

[44] Horton, A. J., Hak, K. M., Steffan, R. J., Foster, J. W., Bej, A. K., Antonie Van Leeuwenkoek 2000, 77, 13-20.

[45] Kim, B. H., Bang, I. S., Lee, S. Y., Hong, S. K. et al., J. Bacteriol. 2001, 183, 5580-5588.

[46] Av-Gay, Y., Aharonowitz, Y., Cohen, G., Nucleic Acids Res. $1992,20,5478$

[47] Julseth, C. R., Inniss, W. E., Can. J. Microbiol. 1990, 36, 519524

[48] Vishnivetskaya, T., Kathariou, S., McGrath, J., Gilichinsky, D., Tiedje, J. M., Extremophiles 2000, 4, 165-173.

[49] Vishnivetskaya, T. A., Kathariou, S., Appl. Environ. Microbiol. 2005, 71, 6954-6962.

[50] Ponder, M. A., Gilmour, S. J., Bergholz, P. W., Mindock, C. A. et al., FEMS Micriobiol. Ecol. 2005, 53, 103-115.

[51] Aebersold, R., Mann, M., Nature 2003, 422, 198-207.

[52] Kachman, M. T., Wang, H., Schwartz, D. R., Cho, K. R., Lubman, D. M., Anal. Chem. 2002, 74, 1779-1791.

[53] Kreunin, P., Urquidi, V., Lubman, D. M., Goodison, S., Proteomics 2004, 4, 2754-2765.

[54] Wall, D. B., Parus, S. J., Lubman, D. M., J. Chromatogr. $B$ Anal. Technol. Biomed. Life Sci. 2002, 774, 53-58.

[55] Wang, Y., Wu, R., Cho, K. R., Shedden, K. A. et al., Mol. Cell. Proteomics 2006, 5, 43-52.

[56] Yan, F., Subramanian, B., Nakeff, A., Barder, T. J. et al., Anal. Chem. 2003, 75, 2299-2308.

[57] Zhu, K., Miller, F. R., Barder, T. J., Lubman, D. M., J. Mass Spectrom. 2004, 39, 770-780.

[58] Zhu, K., Kim, J. K., Yoo, C., Miller, F. R., Lubman, D. M., Anal. Chem. 2003, 75, 6209-6217.

[59] Zheng, S., Schneider, K. A., Barder, T. J., Lubman, D. M., Biotechniques 2003, 35, 1202-1212.

[60] Jensen, O. N., Podtelejnikov, A. V., Mann, M., Anal. Chem. 1997, 69, 4741-4750.

[61] Ojima, N., Masuda, K., Tanaka, K., Nishimura, O., J. Mass Spectrom. 2005, 40, 380-388.

[62] Nakanishi, T., Ohtsu, I., Furuta, M., Ando, E., Nishimura, O., J. Proteome Res. 2005, 4, 743-747. 
[63] Koy, C., Mikkat, S., Raptakis, E., Suttion, C. et al., Proteomics 2003, 3, 851-858.

[64] Ponder, M. A., Center for Genomic and Evolutionary Studies on Microbial Life at Low Temperatures, Department of Microbiology and Molecular Genetics, Michigan State University, East Lansing 2006.

[65] Hesterkamp, T., Bukau, B., FEBS Lett. 1996, 385, 67-71.

[66] Valent, Q. A., Kendall, D. A., High, S., Kusters, R. et al., EMBO J. 1995, 14, 5494-5505.

[67] Lill, R., Crook, E., Guthrie, B., Wickner, W., Cell 1988, 54, 1013-1018.

[68] Jones, P. G., VanBogelen, R. A., Neidhardt, F. C., J. Bacteriol. 1987, 169, 2092-2095.

[69] Jones, P. G., Inouye, M., Mol. Microbiol. 1994, 11, 811-818.
[70] Salotra, P., Singh, D. K., Seal, K. P., Krishna, N. et al., FEMS Mcirobiol. Lett. 1995, 131, 57-62.

[71] Brissette, J. L., Russel, M., Weiner, L., Model, P., Proc. Natl. Acad. Sci. USA 1990, 87, 862-866.

[72] Model, P., Jovanovic, G., Dworkin, J., Mol. Microbiol. 1997, $24,255-261$.

[73] Kleerebezem, M., Tommassen, J., Mol. Microbiol. 1993, 7, 947-956.

[74] Kleerebezem, M., Crielaard, W., Tommassen, J., EMBO J. 1996, 15, 162-171.

[75] Feller, G., Gerday, C., CMLS Cell. Mol. Life Sci. 1997, 53, 830841.

[76] Mathy, N., Jarrige, A.-C., Robert-Le Meur, M., Portier, C., J. Bacteriol. 2001, 183, 3848-3854. 